\title{
PEMBERLAKUAN KURIKULUM SD/MI TAHUN 2013 DAN IMPLIKASINYA TERHADAP UPAYA MEMPERBAIKI PROSES PEMBELAJARAN MELALUI PTK
}

\author{
Mawardi \\ mawardiu@gmail.com \\ Program Studi Pendidikan Guru Sekolah Dasar -FKIP- UKSWSalatiga
}

\begin{abstract}
ABSTRAK
Konsekuensi utama pemberlakuan kurikulum 2013 untuk jenjang SD/MI diantaranya pada cara mensinergikan pendekatan, model dan standar proses pembelajaran, serta cara menyusun dan melakukan penilaian. Dua komponen utama sistem pembelajaran ini merupakan komponen yang sangat erat kaitannya dengan peningkatan mutu pembelajaran. Pendekatan, model dan standar proses pembelajaran berkaitan dengan jaminan mutu prosesnya, sedangkan komponen penilaian berkaitan dengan akurasi dan validitas pengukuran mutu pembelajaran tersebut. Pendekatan saintifik (5M) yang meliputi keterampilan proses mengamati, menanya, mengumpulkan informasi, mengasosiasi dan mengkomunikasikan perlu disinergikan dengan standar proses eksplorasi, elaborasi, dan konfirmasi (EEK). Kedua keterampilan (5M dan EK) inilah yang menjadi pemandu bagi guru untuk memilih model (dan metode) pembelajaran serta alat penilaian otentik yang sesuai. Dalam rangka membantu para guru untuk mengimplemantasikan kurikulum 2013, Kementerian Pendidikan dan Kebudayaan menyiapkan buku guru dan buku siswa. Namun demikian para guru dapat memodifikasi dan mengembangkan sendiri. Pengembangan instrumen pembelajaran disesuaikan dengan karakteristik para siswa dan lingkungan belajar-nya, sehingga mutu proses dan hasil pembelajaran dapat ditingkatkan. Pengem-bangan mutu pembelajaran seperti ini sekaligus menjadi sarana bagi para guru untuk mengembangkan profesinya secara berkelanjutan. Permasalahannya adalah pemberlakuan kurikulum 2013 berimplikasi pada proses pengembangan keprofesian guru, misalnya bagaimana proses pelaksanaan penelitian tindakan kelas (PTK) yang selama ini telah dilakukan. Rambu-rambu pendekatan, model, sistem penilaian, buku guru dan buku siswa dalam kurikukum 2013 mestinya tidak membatasi ruang gerak guru dalam berinovasi.
\end{abstract}

Kata kunci: kurikulum 2013, proses pembelajaran, PTK

\section{PENDAHULUAN}

Pemberlakukan Kurikulum

2013 untuk SD/MI secara nasional mulai tahun pembelajaran 2014-2015 membawa berbagai konsekuensi. Kon- sekuensi utama pemberlakuan kurikulum 2013 tersebut diantaranya pada cara mensinergikan pendekatan, model dan standar proses pembelajaran, serta 
cara menyusun dan melakukan penilaian. Dua komponen utama erat kaitannya dengan peningkatan mutu pembelajaran. Pendekatan, model dan standar proses pembelajaran berkaitan dengan jaminan mutu prosesnya. Sedangkan komponen penilaian berkaitan dengan akurasi dan validitas pengukuran mutu pembelajaran tersebut. Berkaitan dengan mutu pembelajaran, ketentuan Peraturan Menteri Pendayagunaan Aparatur Negara dan Reformasi Birokrasi Nomor 16 tahun 2009, tentang jabatan guru dan angka kreditnya, mengharuskan para guru untuk melakukan pengembangan keprofesionalannya.

Menurut Suharsimi Arikunto (2006), guru harus mempunyai kemampuan melakukan penelitian sederhana dalam rangka meningkatkan kualitas profesional, khususnya kualitas pembelajaran.Terdapat beberapa jenis penelitian yang dapat dilakukan oleh guru, misalnya penelitian eksperimen, deskriptif dan penelitian tindakan. Dalam praktik pembelajaran, jenis penelitian yang diutamakan dan disarankan kepada guru adalah penelitian tindakan (Suharsimi, 2006). Jenis penelitian ini merupakan penelitian yang sangat tepat untuk meningkatkan kulaitas pembelajaran, dan yang selanjutnya dapat meningkatkan kulaitas pendidikan secara luas. Sehubungan dengan hal tersebut, Suharsimi Arikunto (2010) menga- sistem pembelajaran ini merupakan komponen yang sangat penting. takan bahwa penelitian tindakan, dari istilahnya bertujuan untuk menyelesaikan masalah melalui tindakan nyata, bukan mencermati fenomena tertentu kemudian mendeskripsikan apa yang terjadi dengan fenomena yang bersangkutan. Dalam penelitian tindakan, berarti guru melakukan sesuatu, dengan arah dan tujuan yang jelas, yaitu demi kepentingan peserta didik dalam memperoleh hasil belajar yang memuaskan(Suharsimi Arikunto, 2006).

Berkaitan dengan PTK ini, permasalahan muncul ketika Kurikulum SD/MI tahun 2013 mulai diberlakukan secara nasional untuk semua jenjang kelas (kecuali kelas 3 dan 6). Permalahan tersebut relevan dengan perubahan komponen utama pembelajaran sepertu tersebut di atas. Dalam melaksanakan PTK, guru harus menyesuaikan dengan pendekatan, model, dan sistem penilaian dalam Kurikulum SD/MI tahun 2013. Dengan kata lain perlu penyesuaian PTK pada rancangan pengorganisasian kurikulum menjadi tematik integratif, pendekatan mengarah kepada pendekatan saintifik, model pembelajaran mengarah pada model yang mampu memberikan pengalaman belajar otentik, dan penilaiannnya juga harus mampu mengukur pengalaman otentik siswa terssebut. 
IMPLEMENTASI KURIKULUM 2013

\section{Pengorganisasain kurikulum dengan pendekatan Tematik Integratif}

Pembelajaran tematik integratif merupakan pembelajaran yang menggunakan tema sebagai pemersatu kegiatan pembelajaran yang memadukan beberapa mata pelajaran sekaligus dalam satu kali tatap muka. Pelaksanaan pembelajaran tematik integratif berawal dari tema yang telah dipilih/dikembangkan oleh guru yang sesuai dengan kebutuhan peserta didik. Jika dibandingkan dengan pembelajaran konvensional, pembelajaran tematik integratif ini lebih menekankan pada tema sebagai pemersatu berbagai mata pelajaran, dan keterkaitan berbagai konsep mata pelajaran. Dalam pembelajaran tematik integratif, keterlibatan peserta didik dalam belajar lebih diprioritaskan dan tidak tampak adanya pemisahan antar mata pelajaran satu dengan lainnya.

Kegiatan pembelajaran akan bermakna jika dilakukan dalam lingkungan yang nyaman dan memberikan rasa aman, bersifat individual dan kontekstual, anak mengalami langsung yang dipelajarinya, hal ini akan diperoleh melalui pembelajaran tematik. Pembelajaran yang menggunakan tema untuk mengaitkan beberapa mata pelajaran dapat memberikan pengalaman bermakna kepada peserta didik.
Pembelajaran tematik terpadu berfungsi untuk memberikan kemudahan bagi peserta didik dalam memahami dan mendalami konsep materi yang tergabung dalam tema serta dapat menambah semangat belajar karena materi yang dipelajari merupakan materi yang nyata (kontekstual) dan bermakna bagi peserta didik. Tujuan pembelajaran tematik terpadu adalah: a) mudah memusatkan perhatian pada satu tema atau topik tertentu; b) mempelajari pengetahuan dan mengembangkan berbagai kompetensi muatan pelajaran dalam tema yang sama; c) memiliki pemahaman terhadap materi pelajaran lebih mendalam dan berkesan; d) mengembangkan kompetensi berbahasa lebih baik dengan mengkaitkan berbagai muatan pelajaran lain dengan pengalaman pribadi peserta didik; e) lebih bergairah belajar karena mereka dapat berkomunikasi dalam situasi nyata, seperti bercerita, bertanya, menulis sekaligus mempelajari pelajaran yang lain; f) lebih merasakan manfaat dan makna belajar karena materi yang disajikan dalam konteks tema yang jelas; g) guru dapat menghemat waktu, karena mata pelajaran yang disajikan secara terpadu dapat dipersiapkan sekaligus dan diberikan dalam 2 atau 3 pertemuan bahkan lebih dan atau pengayaan; dan $h$ ) budi pekerti dan moral peserta didik dapat ditumbuh kembangkan dengan mengangkat se- 
jumlah nilai budi pekerti sesuai dengan situasi dan kondisi.

Ciri-ciri pembelajaran tematik terpadu: a) berpusat pada anak; b) memberikan pengalaman langsung pada anak; c) emisahan antar muatan pelajaran tidak begitu jelas (menyatu dalam satu pemahaman dalam kegiatan); d) Menyajikan konsep dari berbagai pelajaran dalam satu proses pembelajaran (saling terkait antar muatan pelajaran yang satu dengan lainnya); e) bersifat luwes (keterpaduan berbagai muatan pelajaran); f) hasil pembelajaran dapat berkembang sesuai dengan minat dan kebutuhan anak (melalui penilaian proses dan hasil belajarnya).

Implementasi Pembelajaran Tematik Terpadu melalui beberapa tahapan yaitu pertama guru mengacu pada tema sebagai pemersatu berbagai muatan pelajaran. Kedua guru melakukan analisis Standar Kompetensi Lulusan, Kompetensi Inti, Kompetensi Dasar dan membuat indikator dengan tetap memperhatikan muatan materi dari Standar Isi. Ketiga membuat hubungan pemetaan antara kompetensi dasar dan indikator dengan tema. Keempat membuat jaringan KD, indikator. Kelima menyusun silabus tematik dan keenam membuat rencana pelaksanaan pembelajaran tematik terpadu dengan menerapkan pendekatan saintifik.

Pola pengorganisasian tema dan sub tema pada buku guru dan buku siswa menggunakan pola Tema Sub tema - Pembelajaran. Jumlah tema pada setiap kelas berkisar antara 6 sampai 9 tema. Pada setiap semester, rata-rata ada $3-5$ tema. Setiap tema ada dijabarkan menjadi 4 -5 sub tema. Masing-masing sub tema disampaikan dalam 6 pembelajaran, dimana pada pembelajaran ke-6 dilakukan evaluasi.

\section{Kedudukan dan fungsi Buku Guru dan Buku Siswa}

Buku Guru dan Buku Siswa berkedudukan dan berfungsi sebagai berikut: a) Pemetaan Kompetensi Dasar (KD) dari Kompetensi Inti (KI) 1 dan 2. Pada buku guru, pemetaan KD dari KI 1 dan 2 disiapkan setiap subtema. Namun dalam jaringan KD harian (tiap PB) KD dari KI 1 dan 2 tidak dimunculkan karena ketercapaiannya diperoleh dari pembelajaran tidak langsung (indirect learning). Harapannya guru bisa memilih aspek spiritual (KI 1) maupun aspek sosial (KI 2) sesuai dengan aktivitas pembelajaran harian yang sedang dilakukan. Berikut ini contoh pemetaan kompetensi dasar dari KI 1 dan KI 2. b) Pemetaan Kompetensi Dasar dari KI 3 dan 4. Pada buku guru pemetaan KD dari KI 3 dan 4 disediakan tiap subtema (mingguan). Pemetaan ini masih akan dijabarkan lagi dalam pemetaan KD harian. c) Pemetaan Kompetensi Dasar tiap PB (harian). Pada buku guru sudah disiapkan 
pemetaan $\mathrm{KD}$ dan indikator pada masing-masing pembelajaran (PB) untuk memudahkan guru mengajar harian. Meskipun telah disediakan pemetaan di setiap PB, guru hendaknya mengkaji apakah masih diperlukan KD tambahan pada pembelajaran hari itu. Untuk kepentingan penyusunan RPP (harian), guru perlu menambahkan $\mathrm{KD}$ dari $\mathrm{KI}$ 1 dan 2 yakni sikap spiritual dan sikap sosial. Penambahan KD bisa melihat pada pemetaan KD dari KI 1 dan 2 pada tiap subtema. Guru hendaknya mencermati indikator setiap KD. Untuk pembelajaran harian, setiap KD minimal dijabarkan dalam satu indikator karena KD tersebut kemungkinan dibelajarkan lagi pada subtema yang lain. Meskipun sudah ada contoh indikator pada buku guru, namun guru perlu mengkaji ulang indikator tersebut.

\section{Pembelajaran Tematik Terpadu pada Buku Guru dan Siswa}

Pada pembelajaran tematik terpadu, kita harus memerhatikan keterpaduan muatan pelajaran. Keterpaduan muatan pelajaran tergambar dari jaringan rencana kegiatan. Pada buku guru telah diberikan contoh tujuan pembelajaran sebagai panduan bagi guru apa yang akan dicapai. Guru diperbolehkan untuk menambah atau merubah tujuan pembelajaran sesuai dengan kondisi peserta didik dan lingkungan temp- at belajar (Kemdikbud, 2014: 45 dan Lampiran Permendikbud No. 57 tahun 2014). Tujuan pembelajaran idealnya memuat A (audience) yakni siswa; B (behavior) yakni kemampuan yang akan dicapai (membedakan, menjelaskan, dll), C (condition) yakni kondisi atau kegiatan yang akan dilakukan siswa (membaca teks, mengamati gambar, diskusi dll); D (degree) tingkatan (dengan benar, sesuai prosedur, dengan santun, percaya diri, dll).

Pada buku siswa terdapat media dan alat bantu dalam pembelajaran. Misalnya, pada Tema 1 Pengalamanku, Subtema 2, Pembelajaran 1 terdapat lagu berjudul Bunda Piara. Selain lagu tersebut, guru dapat menambahkan lagu daerah setempat yang bertema pengalaman masa kecilku. Di dalam buku siswa juga terdapat gambar alat-alat musik ritmik.

Guru dapat menambahkan gambargambar alat musik ritmik khas daerah setempat. (Kemdikbud, 2014: 45 dan Lampiran Permendikbud No. 57 tahun 2014). Demikian pula dengan sumber belajar, materi tidak terbatas pada buku siswa saja. Guru bisa mengajak siswa mengamati lingkungan, membaca buku referensi lain, membaca berita di koran, atau melihat tayangan tentang hewan di TV/ video.Pelaksanaan pembelajaran pada Kurikulum 2013 menggunakan pendekatan scientific yang memuat kegiatan mengamati, menanya, mengumpulkan informasi/eksperimen, mengasosiasi 
atau menalar, dan mengkomunikasikan. Langkah-langkah pembelajaran tersebut telah dituangkan dalam buku guru.

Buku Siswa diarahkan agar siswa lebih aktif dalam mengikuti proses pembelajaran melalui kegiatan mengamati, menanya, menalar, mencoba, berdiskusi serta meningkatkan kemampuan berkomunikasi baik antarteman maupun dengan gurunya.

Guru dapat mengembangkan atau memperkaya materi dan kegiatan lain yang sesuai dengan tujuan pembelajaran yang telah ditetapkan (Kemdikbud, 2014: 42 dan Lampiran Permendikbud No. 57 tahun 2014).

\section{Cara Penggunaan Buku Guru dan} Buku Siswa

Buku Guru berhubungan dengan Buku Siswa, karena Buku Guru memandu pembelajaran yang sesuai dengan Buku Siswa. Penggunaan Buku Guru dan Buku Siswa tersebut dapat dijelaskan sebagai berikut. (Kemdikbud, 2014: 46 dan Lampiran Permendikbud No. 57 tahun 2014).

a) Bukalah Buku Guru tema tertentu.

Cermatilah halaman yang berjudul Tentang Buku Guru dan Bagaimana Menggunakan Buku Guru. Ikutilah petunjuk yang ada pada halaman tersebut. b) Rancangan pembelajaran setiap Tema dibagi dalam rancangan subtema yang tampak pada jaringan subtema atau Pemetaan Kompetensi Dasar pada Buku Guru. Guru diharap mencermati jaringan subtema yang memuat Kompetensi Dasar Muatan Pelajaran yang akan dicapai pada satu minggu.

c) Jaringan subtema terdiri atas jaringan subtema untuk KD dari KI 1 dan 2, serta jaringan subtema untuk KD dari KI 3 dan KI 4.

d) Jaringan subtema KD dari KI 3 dan KI 4 dijabarkan lagi menjadi jaringan Kompetensi Dasar dan Indikator setiap pembelajaran.

e) Cermatilah jaringan setiap pembelajaran. Pemetaan Indikator pada Buku Guru memuat Kompetensi Dasar yang akan dicapai berdasarkan rumusan indikatornya.

f) Setelah mencermati indikator yang akan dicapai pada setiap pembelajaran, cermatilah tujuan pembelajaran yang terdapat di Buku Guru. 
g) Perhatikan langkahlangkah kegiatan yang terdapat pada Buku Guru.

h) Hubungkanlah langkahlangkah kegiatan pembelajaran pada Buku Guru dengan penjabaran kegiatan pembelajaran yang ada di Buku Siswa.

i) Guru dapat memodifikasi rancangan pembelajaran di Buku Guru untuk disesuaikan dengan kondisi kelas. Apabila rancangan berubah, maka guru harus membuat penyesuaian juga dalam pembelajarannya.

j) Pada Buku Guru juga terdapat media, alat, dan sumber pembelajaran yang digunakan sesuai dengan pembelajaran yang akan dilaksanakan. Namun, guru juga dapat mengganti atau menambahkan media, alat, dan sumber pembelajaran sesuai dengan kondisi kelas.

k) Cermatilah halaman Remedial dan Pengayaan yang terdapat pada Buku Guru sebagai panduan ketika guru akan melaksanakan kegiatan tersebut.

1) Di dalam Buku Guru terdapat contoh-contoh teknik penilaian, guru dapat membuka halaman penilaian sebagai panduan menilai siswa.

Pendekatan tematik integratif dalam kurikulum SD/MI 2013 disamping terintegrasi dalam hal materi lintas matapelajaran, juga terintegrasi dalam ranah kompetensi pembelajaran. Maknanya bahwa dalam setiap pembelajaran, guru dituntut untu kmampu mengintegrasikan perolehan pembelajaran pada tiga ranah (kognitif, Afektif dan Psikomotorik/Keteampilan). Integrasi ketiga ranah tersebut dapat dicermati dari pijakan teori seperti dalam Gambar berikut. 


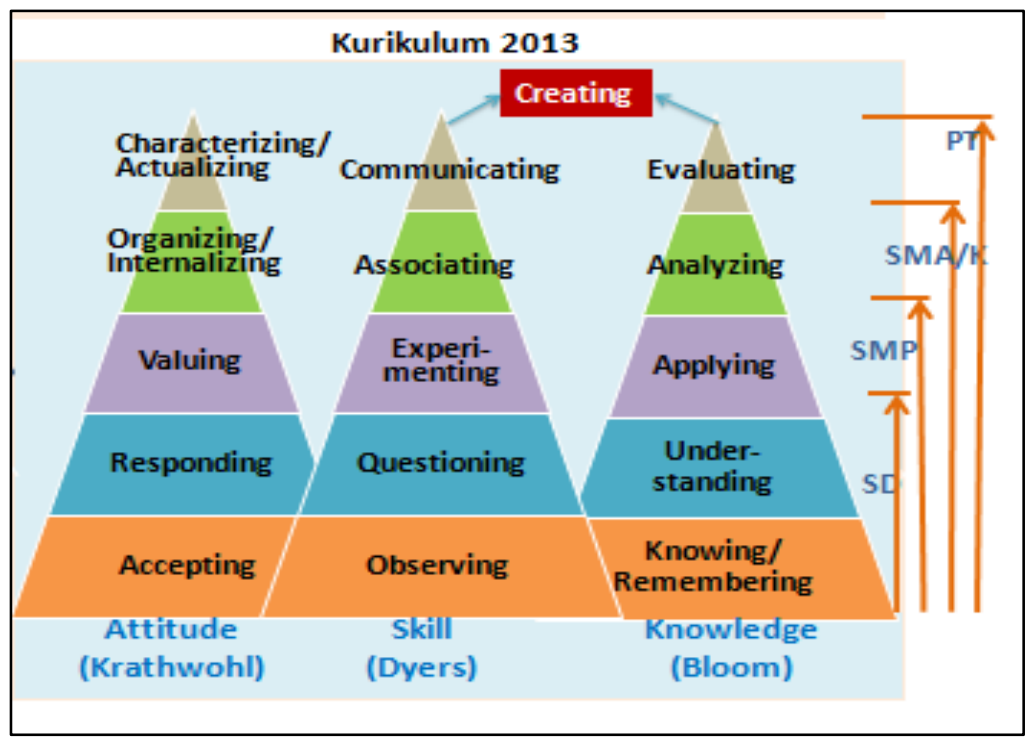

Gambar Integrasi ranah kompetensi pembelajaran

Pendekatan, Model, dan Standar Proses Pembelajaran dalam

\section{Kurikulum 2013 SD/MI}

Dalam dokumen Kurikulum SD/MI 2013, pendekatan yang digunakan adalah Saintifik. Model pembelajarannya adalah model Problem Based Learning (PBL), Project Based Learning (PjBL), Problem Based Learing, Discovery Learning dan model-model lain yang mengandung muatan proses saintifik maupun pendidikan nilai-nilai. Berkaitan dengan standar proses pembelajaran tetap dipertahankan standar EEK (Eksplorasi,Elaborasi dan Konfirmasi).

\section{a. Pendekatan Saintifik/}

Pendekatan Ilmiah
Proses pembelajaran dapat dipadankan dengan suatu proses ilmiah, karena itu Kurikulum 2013 mengamanatkan esensi pendekatan saintifik dalam pembelajaran. Pendekatan saintifik diyakini sebagai titian emas perkembangan dan pengembangan sikap, keterampilan, dan pengetahuan peserta didik. Dalam pendekatan atau proses kerja yang memenuhi kriteria ilmiah, para ilmuan lebih mengedepankan pelajaran induktif (inductive reasoning) dibandingkan dengan penalaran deduktif (deductive reasoning).

Penalaran deduktif melihat fenomena umum untuk kemudian menarik simpulan yang spesifik. Sebaliknya, penalaran induktif memandang fenomena 
Tabel 1. Keterkaitan antara Langkah Pembelajaran dengan Kegiatan Belajar

\begin{tabular}{|c|c|}
\hline $\begin{array}{c}\text { Langkah } \\
\text { Pembelajaran }\end{array}$ & Kegiatan Belajar \\
\hline Mengamati & $\begin{array}{l}\text { Membaca, mendengar, menyimak, melihat (tanpa atau } \\
\text { dengan alat) }\end{array}$ \\
\hline Menanya & $\begin{array}{l}\text { Mengajukan pertanyaan tentang informasi yang tidak } \\
\text { dipahami dari apa yang diamati atau pertanyaan untuk } \\
\text { mendapatkan informasi tambahan tentang apa yang diamati }\end{array}$ \\
\hline $\begin{array}{l}\text { Mengumpul- } \\
\text { kan informasi/ } \\
\text { eksperimen }\end{array}$ & $\begin{array}{l}\text { - melakukan eksperimen } \\
\text { - membaca sumber lain selain buku teks } \\
\text { - mengamati objek/ kejadian/ } \\
\text { - aktivitas } \\
\text { - wawancara dengan narasumber }\end{array}$ \\
\hline $\begin{array}{l}\text { Mengasosiasik } \\
\text { an/ mengolah } \\
\text { informasi }\end{array}$ & $\begin{array}{l}\text { - mengolah informasi yang sudah dikumpulkan baik dari } \\
\text { hasil kegiatan mengumpulkan/ eksperimen mau pun hasil } \\
\text { dari kegiatan mengamati dan kegiatan mengumpulkan } \\
\text { informasi. } \\
\text { - Pengolahan informasi yang dikumpulkan dari yang } \\
\text { bersifat menambah keluasan dan kedalaman sampai } \\
\text { kepada pengolahan informasi yang bersifat mencari solusi } \\
\text { dari berbagai sumber yang memiliki pendapat yang } \\
\text { berbeda sampai kepada yang bertentangan. }\end{array}$ \\
\hline $\begin{array}{l}\text { Mengkomunik } \\
\text { asikan }\end{array}$ & $\begin{array}{l}\text { Menyampaikan hasil pengamatan, kesimpulan berdasarkan } \\
\text { hasil analisis secara lisan, tertulis, atau media lainnya. }\end{array}$ \\
\hline
\end{tabular}

atau situasi spesifik untuk kemudian menarik simpulan secara keseluruhan. Sejatinya, penalaran induktif menempatkan bukti-bukti spesifik ke dalam relasi ide yang lebih luas. Metode ilmiah umumnya menempatkan fenomena unik dengan kajian spesifik dan detail untuk kemudian merumuskan simpulan umum. Metode ilmiah merujuk pada teknik-teknik investigasi atas suatu atau beberapa fenomena atau gejala, memperoleh pengetahuan baru, atau mengoreksi dan memadukan pengetahuan sebelumnya. 


\section{b. Langkah-langkah Pembelajaran dengan Pendekatan Ilmiah}

Menurut Permendikbud Nomor 81 A Tahun 2013 lampiran IV, proses pembelajaran terdiri atas lima pengalaman belajar pokok yaitu:
a. Mengamati (M-1)
b. Menanya (M-2)
c. mengumpulkan informasi/eksperimen (M-3)
d. mengasosiasikan/mengolah informasi (M-4) dan
e. mengkomunikasikan (M-5).

Kelima pembelajaran pokok tersebut dapat dirinci dalam berbagai kegiatan belajar sebagaimana tercantum dalam tabel 1 .

\section{c. Pemetaan Integrasi Pendekatan Saintifik, Model Pembelajaran Inovatif dan Komponen EEK dalam RPP Kurikulum 2013}

Tabel 2. Contoh Pemetaan Integrasi Pendekatan Saintifik, Model Pembelajaran Inovatif dan Komponen EEK dalam RPP Kurikulum 2013

\begin{tabular}{|c|c|c|c|c|c|c|c|}
\hline \multirow{2}{*}{ Model } & \multirow[b]{2}{*}{ Sintak } & \multirow{2}{*}{ EEK } & \multicolumn{5}{|c|}{ Pendekatan Saintifik } \\
\hline & & & $M-1$ & $M-2$ & $M-3$ & $M-4$ & $M-5$ \\
\hline \multirow{5}{*}{$\begin{array}{l}\text { Problem } \\
\text { Based } \\
\text { Learning } \\
\text { (PBL) }\end{array}$} & $\begin{array}{l}\text { 1. Memberikan orientasi permasalahan } \\
\text { pada siswa }\end{array}$ & $\mathrm{E}$ & V & & & & \\
\hline & 2. Mengorganisir siswa untuk meneliti & $E$ & & $\sqrt{ }$ & & & \\
\hline & 3. Melakukan penyelidikan & $\mathrm{El}$ & & & $\sqrt{ }$ & & \\
\hline & 4. Mempresentasikan hasil pemecahan & $\mathrm{El}$ & & & & $\mathrm{V}$ & $\mathrm{V}$ \\
\hline & $\begin{array}{l}\text { 5. Mengevaluasi proses pemecahan } \\
\text { masalah }\end{array}$ & K & & & & & V \\
\hline \multirow{5}{*}{$\begin{array}{l}\text { Problem } \\
\text { Solving } \\
\text { (Dewey) }\end{array}$} & 1. Mengidentifikasi masalah & $\mathrm{E}$ & $\mathrm{V}$ & & & & \\
\hline & $\begin{array}{l}\text { 2. Membimbing siswa untuk memperjelas } \\
\text { dan membatasi masalah }\end{array}$ & $\mathrm{E}$ & & $\sqrt{ }$ & & & \\
\hline & $\begin{array}{l}\text { 3. Mengumpulkan informasi ataupun } \\
\text { data }\end{array}$ & $\mathrm{El}$ & & & $\sqrt{ }$ & & \\
\hline & $\begin{array}{l}\text { 4. Menyusun hipotesis dan } \\
\text { menyeleksinya }\end{array}$ & $\mathrm{El}$ & & & & $\sqrt{ }$ & \\
\hline & $\begin{array}{l}\text { 5. Melakukan pemecahan masalah } \\
\text { sekaligus menguji hipotesis untuk } \\
\text { disimpulkan }\end{array}$ & K & & & & V & \\
\hline \multirow{3}{*}{$\begin{array}{l}\text { Discovery } \\
\text { Learning }\end{array}$} & $\begin{array}{l}\text { 1. Stimulation (stimulasi/pemberian } \\
\text { rangsangan) }\end{array}$ & $\mathrm{E}$ & $\sqrt{ }$ & & & & \\
\hline & $\begin{array}{l}\text { 2. Problem statement (pernyataan/ } \\
\text { identifikasi masalah) }\end{array}$ & $\mathrm{E}$ & & $\sqrt{ }$ & & & \\
\hline & 3. Data collection (Pengumpulan Data). & $\mathrm{El}$ & & & $\mathrm{V}$ & & \\
\hline
\end{tabular}


Scholaria, Vol. 4, No. 3, September 2014: 107-121

\begin{tabular}{|c|c|c|c|c|c|c|c|}
\hline & 4. Data Processing (Pengolahan Data) & $\mathrm{El}$ & & & & $\mathrm{V}$ & \\
\hline & 5. Verification (Pembuktian) & $\mathrm{K}$ & & & & $\sqrt{ }$ & \\
\hline & $\begin{array}{l}\text { 6. Generalization (menarik } \\
\text { kesimpulan/generalisasi). }\end{array}$ & $\mathrm{K}$ & & & & $\sqrt{ }$ & $\sqrt{ }$ \\
\hline \multirow{6}{*}{$\begin{array}{l}\text { Project } \\
\text { Based } \\
\text { Learning } \\
\text { (PjBL) }\end{array}$} & 1. Menentukan pertanyaan mendasar & $E$ & $\sqrt{ }$ & $\mathrm{V}$ & & & \\
\hline & 2. Menyusun perencanaan proyek & $\mathrm{E}$ & & $\mathrm{V}$ & & & \\
\hline & $\begin{array}{l}\text { 3. Menyususun dan melaksanakan } \\
\text { aktifitas proyek }\end{array}$ & $\mathrm{El}$ & & & $\sqrt{ }$ & & \\
\hline & 4. Memonitor kemajuan proyrek & $\mathrm{El}$ & & & $\mathrm{V}$ & & \\
\hline & 5. Menilai hasil proyek & $\mathrm{K}$ & & & & $\mathrm{V}$ & $\sqrt{ }$ \\
\hline & 6. Mengevaluasi pengalaman (refleksi) & $\mathrm{K}$ & & & & & $\sqrt{ }$ \\
\hline
\end{tabular}

\section{Penilaian Pembelajaran}

Penilaian yang disarankan dalam Kurikulum 2013 adalah penilaian autentik. Penilaian autentik diartikan sebagai penilaian atas produk dan kinerja yang berhubungan dengan pengalaman kehidupan nyata peserta didik. Dalam penilaian autentik digunakan alat ukur yang bermakna secara signifikan atas hasil belajar peserta didik untuk ranah sikap, keterampilan, dan pengetahuan. Istilah autentik merupakan sinonim dari asli, nyata, valid, atau reliabel. Penilaian autentik memiliki relevansi kuat terhadap pendekatan tematik integratif dan saintifik sesuai dengan tuntutan Kurikulum 2013. Penilaian autentik akan mampu menggambarkan kompetensi siswa dalam mengamati, menanya, mengumpulkan informasi, menalar dan mengkomunikasikan.

Kurikulum 2013 membagi kompetensi sikap menjadi dua, yaitu sikap spiritual yang terkait dengan pembentukan peserta didik yang beriman dan bertakwa, dan sikap sosial yang terkait dengan pembentukan peserta didik yang berakhlak mulia, mandiri, demokratis, dan bertanggung jawab. Sikap spiritual sebagai perwujudan dari menguatnya interaksi vertikal dengan Tuhan Yang Maha Esa, sedangkan sikap sosial sebagai perwujudan eksistensi kesadaran dalam upaya mewujudkan harmoni kehidupan. Pada jenjang SD, kompetensi sikap spiritual mengacu pada KI-1: Menghargai dan menghayati ajaran agama yang dianutnya, sedangkan kompetensi sikap sosial mengacu pada KI-2: Menghargai dan menghayati perilaku jujur, disiplin, tanggung jawab, peduli (toleransi, gotong royong), santun, percaya diri, dalam berinteraksi secara efektif dengan lingkungan sosial dan alam dalam jangkauan pergaulan dan keberadaannya. Berdasarkan rumusan KI-1 dan KI-2 di atas, penilaian sikap pada jenjang SD mencakup sikap spiritual menghargai dan menghayati ajaran agama yang dianut. Sedangkan sikap sosial mencakup sikap jujur, disiplin, tanggung jawab, toleran, 
gotong-royong, santun, dan percaya diri.Penilaian sikap dapat dilakukan menggunakan teknik observasi, penilaian diri, penilaian antarteman, dan jurnal.

Penilaian pengetahuan merupakan penilaian yang berkaitan dengan aspek penguasaan materi pembelajaran secara kognitif. Aspek Pengetahuan dapat dinilai dengan cara berikut tes tulis yang soal dan jawabannya tertulis berupa pilihan ganda, isian, Benarsalah, menjodohkan, dan uraian.Tes Lisan berupa pertanyaan- pertanyaan yang diberikan guru secara ucap (oral) sehingga peserta didik merespon pertanyaan tersebut secara ucap juga, sehingga menimbulkan keberanian. Jawaban dapat berupa kata, frase, kalimat maupun faragraf yang diucapkan. Penugasan, yaitu penilaian yang dilakukan oleh pendidik yang dapat berupa pekerjaan rumah baik secara individu ataupun kelompok sesuai dengan karakteristik tugasnya. Teknik penilaian kompetensi pengetahuan dilakukan dengan tes tulis, tes lisan, dan penugasan. Tiap-tiap teknik tersebut dilakukan melalui instrumen tertentu yang relevan.

Aspek keterampilan dapat dinilai dengan kerja praktik, yaitu suatu penilaian yang meminta siswa untuk melakukan suatu tugas pada situasi yang sesungguhnya yang mengaplikasikan pengetahuan dan keterampilan yang dibutuhkan. Misalnya tugas memainkan alat musik, menggunakan mikroskop, menyanyi, bermain peran, menari. Penilaian Projek merupakan penilaian terhadap tugas yang mengandung investigasi dan harus diselesaikan dalam periode/waktu tertentu. Tugas tersebut meliputi perencanaan, pelaksanaan, pelaporan. Projek juga akan memberikan informasi tentang pemahaman dan pengetahuan siswa pada pembelajaran tertentu, kemampuan siswa dalam mengaplikasikan pengetahuan, dan kemampuan siswa untuk mengkomunikasikan informasi. Penilaian projek sangat dianjurkan karena membantu mengembangkan keterampilan berpikir tinggi (berpikir kritis, pemecahan masalah, berpikir kreatif) peserta didik. Contoh projek misalnya membuat laporan pemanfaatan energi di dalam kehidupan, membuat laporan hasil pengamatan pertumbuhan tanaman. Penilaian aspek keterampilan juga bisa dilakukan dengan portofolio, yaitu kumpulan karaya siswa yang didokumentasikan selama periode tertentu.

\section{IMPLIKASI}

Seperti telah disampaikan pada bagian pendahuluan, Suharsimi Arikunto (2006) menyatakan bahwa guru harus mempunyai kemampuan melakukan penelitian sederhana dalam rangka meningkatkan kualitas profesional, khususnya kualitas pembelajaran. Dalam praktik pembelajaran, 
jenis penelitian yang diutamakan dan disarankan kepada guru adalah penelitian tindakan. Jenis penelitian ini merupakan penelitian yang sangat tepat untuk meningkatkan kulaitas pembelajaran, dan yang selanjutnya dapat meningkatkan kulaitas pendidikan secara luas.

PandanganSuharsimi Arikunto tersebut menegaskan bahwa apapun kurikulum yang berlaku, para guru berkewajiban melakukan perbaikan mutu proses pembelajarannya. Tak terkecuali setelah pemberlakuan kurikulum 2013 berdasarkan Permendikbud No.67 Tahun 2013 juncto Permendikbud No. 57 Tahun 2014, guru terikat untuk melakukan tindakan perbaikan pembelajarannya. Telah diuraikan di atas, bahwa implementasi kurikulum 2013 adalah pembelajaran yang dirancang dengan seksama berdasarkan pendekatan saintifik, pengorganisasian materi dialkukan dengan menggunakan model tematik integratif, disinergikan dengan modelmodel pembelajaran inovatif, dan dilakukan penilaian dengan model penilaian otentik. Tuntutan implementasi kurikulum 2013 ini tidaklah mudah, lebih-lebih jika akan melakukan perbaikan pembelajaran melalui PTK. Oleh karena itu perlu upaya yang sungguh-sungguh untuk memahami dan melaksanakannya dengan baik.

Beberapa catatan implikatif pemberlakuan kurikulum 2013 dalam kaitannya dengan proses merancang dan melakukan PTK berikut ini dapat digunakan sebagai rambu-rambu bagi guru yang akan melakukan PTK.

1. PTK dilakukan dalam rangka memperbaiki pembelajaran tematik integratif berdasarkan Kurikulum 2013.

2. Siklus pembelajaran minimal 2 siklus. Masing- masing siklus, jika mengacu pada Buku Guru dan Buku Siswa terdiri dari satu Sub-tema dengan 6 pembelajaran (1 sd 6, pembelajaran ke- 6 untuk Evaluasi). Namun jika mengacu pada ramburambu implementasi Kurikulum 2013, yang berisi kemungkinan guru melakukan modifikasi rancangan pembelajaran (Kemendikbud, 2014: 42, 45,46) satu pembelajaraan $(\mathrm{PB})$ dapat dimaknai sebagai satu siklus. Dengan catatan perlu memodifikasi rancangan dan materi dalam Buku Siswa dengan menambahkan evaluasi pembelajaran pada setiap akhir pertemuan.

3. Kaitan dengan satuan amatannya, boleh mengamati proses dan dampak tindakan dalam satu muatan matapelajaran yang dipandang masih bermasalah. Namun jika memungkinkan dan permasalahannya menyeluruh bisa menggunakan keseluruhan mapel yang diintegrasikan.

4. Pendekatan pembelajaran menggunakan pendekatan saintifik. 
5. Model pembelajaran disarankan menggunakan model pembelajaran PBL, Problem Solving, PJ-BL, Discovery Learning dan model lain yang relevan dengan pendekatan saintifik.

6. Variabel PTK yang diamati dan diukur minimal dua variabel, yaitu proses pembelajaran sesuai dengan sintak modelnya atau keterampilan saintifik tertentu (tidak harus semua/5M) dan variabel dampak (hasil belajar).

7. Instrumen pengumpulan data menggunakan instrumen tes untuk variabel dampak tindakan (hasil belajar) dan penilaian otentik jenis non tes (misalnya rubrik keterampilan melakukan percobaan) untuk variabel proses.

\section{PENUTUP}

Sebagai catatan penutup, dapat disampaikan bahwa ruh implementasi kurikulum 2013 adalah pembelajaran yang dirancang dengan seksama berdasarkan pendekatan saintifik, pengorganisasian materi dialkukan dengan menggunakan model tematik integratif, disinergikan dengan modelmodel pembelajaran inovatif, dan dilakukan penilaian dengan model penilaian otentik.

Implikasi pemberlakuan Kurikulum 2013 dalam penyusunan PTK antara lain adalah: 1) PTK dilakukan dalam rangka memperbaiki pembelajaran tematik integratif berdasarkan Kurikulum 2013. 2) Siklus pembelajaran minimal 2 siklus. Masingmasing siklus, jika mengacu pada Buku Guru dan Buku Siswa terdiri dari satu Sub-tema dengan $\underline{6}$ pembelajaran (1 sd 6, pembelajaran ke- 6 untuk Evaluasi).3) Satuan amatannya, boleh mengamati proses dan dampak tindakan dalam satu muatan matapelajaran yang dipandang masih bermasalah. Namun jika memungkinkan dan permasalahannya menyeluruh bisa menggunakan keseluruhan muatan mapel yang diintegrasikan. 4) Pendekatan pembelajaran menggunakan pendekatan saintifik yang disinergikan dengan model pembelajaran inovatif yang secara potensial mengandung unsurunsur pendekatan saintifik. Misalnya model pembelajaran $P B L$, Problem Solving, PJ-BL, Discovery Learning. 5) Variabel PTK yang diamati dan diukur minimal dua variabel, yaitu proses pembelajaran sesuai dengan sintak modelnya atau keterampilan saintifik tertentu (tidak harus semua/5M) dan variabel dampak (hasil belajar).6) Instrumen pengumpulan data menggunakan instrumen tes untuk variabel dampak tindakan (hasil belajar) dan penilaian otentik jenis non tes (misalnya rubrik keterampilan melakukan percobaan) untuk variabel proses. 
Scholaria, Vol. 4, No. 3, September 2014: 107-121

\section{DAFTAR PUSTAKA}

Kemendikbud. (2014). Materi Pelatihan Guru Implementasi Kurikulum 2013 Tahun 2014. Jakarta: Badan Pengembangan Sumber Daya Manusia Pendidikan dan Kebudayaan dan Penjaminan Mutu Pendidikan Kementerian Pendidikan dan Kebudayaan.

(2013). Salinan Permendikbud No. 67 Tahun 2013 tentang Kompetensi Dasar dan Struktur Kurikulum SD/MI.

(2013). Salinan Lampiran Permendikbud No. 67 Tahun 2013 tentang Kompetensi Dasar dan Struktur Kurikulum SD/MI.

(2014). Salinan Permendikbud No. 57 Tahun 2014 tentang Kompetensi Dasar dan Struktur Kurikulum SD/MI.

(2014). Salinan Lampiran Permendikbud No. 67 Tahun 2013 tentang Kompetensi Dasar dan Struktur Kurikulum SD/MI.

-- (2013). Salinan Permendikbud No. 65 Tahun 2013 tentang Standar Proses. Jakarta: Kementerian Pendidikan dan Kebudayaan

(2013). Salinan Lampiran Permendikbud No. 65 Tahun 2013 tentang

Standar Proses. Jakarta: Kementerian Pendidikan dan Kebudayaan

(2013). Salinan Permendikbud No. 66 Tahun 2013 tentang Standar

Penilaian. Jakarta: Kementerian Pendidikan dan Kebudayaan

(2013). Salinan Lampiran Permendikbud No. 66 Tahun 2013 tentang

Standar Penilaian. Jakarta: Kementerian Pendidikan dan Kebudayaan

(2013). Permendikbud No. 81a Tahun 2013 tentang Implementasi

Kurikulum 2013. Jakarta: Kementerian Pendidikan dan Kebudayaan.

Suharsimi Arikunto. (2010). Penelitian Tindakan Kelas. Jakarta: Bumi Aksara. 